\title{
The criminalisation of paying for sex in England and Wales: how gender and power are implicated in the making of policy
}

\author{
NATASHA MULVIHILL \\ Centre for Gender and Violence Research, University of Bristol, UK \\ E-mail: natasha.mulvihill@bristol.ac.uk
}

\begin{abstract}
This article considers how gender and power are implicated in how prostitution policy is translated from initial proposal to enactment in law. The analysis brings together Freeman's proposal for "policy translation" (2009) and Connell's work on "hegemonic masculinity" (1987 with Messerschmidt 2005) to examine Hansard and other United Kingdom Parliament documents relating to Clause 13/14 of the Policing and Crime Bill 2008-2009, a proposal to criminalise the purchase of sex in England and Wales. It is argued here that hegemonic masculinity is implicated in how "responsibility" and "exploitation" in relation to sex purchase are disputed and defined within the Parliamentary debates on Clause $13 / 14$, and this in turn informed the version of criminalisation that emerged as authoritative. This article reflects finally on how far mapping the translation of policy can elucidate the operation of gender and power within the policy process.
\end{abstract}

Key words: gender, parliament, policy, power, prostitution, translation

\section{Background}

In the British system, the government delivers its legislative agenda by proposing draft statements of law or "Bills", which are then revised through an established process of readings, debates and committee hearings in both the House of Commons and the House of Lords. The final agreed version of a Bill receives Royal Assent and duly passes into law as an "Act". A verbatim report of these Parliamentary proceedings is captured for public record in Hansard, which therefore provides a fertile resource for researchers interested in examining how policy and law are contested. My aim in this article is to explore how gender and power relations are 
implicated in the way that English prostitution policy is translated through the Parliamentary process, from its initial proposal within a bill clause or amendment to the final version that emerges in law following debate and revision. I use Connell's (1987) concept of "hegemonic masculinity" here to provide a framework for analysing gender and power relations, and focus on the partial criminalisation of sex purchase proposed in the Policing and Crime Bill 2008-2009 as a case study of English prostitution policy.

The findings presented in this article are one strand of a wider piece of work using what I term a "multianalysis" approach, where different analytical techniques were applied to the same set of Parliamentary data. The other strands involved considering how gender and power were implicated in who spoke on criminalisation (through analysing the substance of speakers' contributions by gender) and in what they said (through both a thematic analysis and a critical discourse analysis). In the concluding section, I reflect briefly on how far the operation of gender and power in the policy process is illuminated by tracking policy translation, both as a method in isolation and as part of this multianalysis approach.

I first turn to the definition of key terms. "Prostitution" is defined here as an encounter where an individual pays another individual (in financial or other terms) to secure "some form of sexual/bodily contact ... most commonly penetrative sex" (Kelly et al. 2009, 7). Although economic inequality, ethnicity or immigration status, for example, may intersect the sex seller-sex buyer relationship, gender is the defining pattern across the different settings for prostitution in England. Gender describes the socially recognised attributes or characteristics ("femininity" or "masculinity") associated with biological sex ("female" and "male"). Following West and Zimmerman, I recognise the term "gender" "not as a simple property of individuals but as an integral dynamic of social orders" $(1987,147)$ and acknowledge that gender identities are both constituted through interaction but also constrained by existing institutional arrangements (146).

Prostitution is a practice patterned by gender. The most recent set of British National Surveys of Sexual Attitudes and Lifestyles (referred to as "Natsal 3"), carried out by researchers from University College London, the London School of Hygiene \& Tropical Medicine and NatCen Social Research, asked respondents whether they have "Paid for sex in the past 5 years". Around $4 \%$ of men responded positively to this question and $0.1 \%$ of women. ${ }^{1}$ Men pay for sex generally from women, but also from other men and children. Of course, Natsal 3 also suggests that $96 \%$ of men have not paid for sex in the last five years, which deserves further attention

\footnotetext{
${ }^{1}$ Natsal 3 was conducted between 2010 and 2012 and findings are available at: http://www. natsal.ac.uk/natsal-3.aspx (12 November 2016).
} 
(although a broader definition of consumption of commercial sex to include pornography and sexual entertainment venues, for example, may alter this figure significantly). It is argued here that, within the social practice of prostitution, it is overwhelmingly men paying for sex because of the current configuration of gender-power relations and because of the association constructed between masculinity and sexuality. As Person observed, "in men, gender appears to 'lean' on sexuality" (1980, 619). Similarly, Coy et al. found that buying sex is "embedded in normative constructions of masculinity" $(2007,21)$. Men pay for sex not because they need to, but because they can.

The framework for understanding gender and power used in this research draws on Connell's (1987) work on hegemonic masculinity (with Messerschmidt 2005). Putting a distance between both traditional patriarchal accounts and postmodern accounts, Connell and Messerschmidt stress that "the concept of hegemonic masculinity is not intended as a catchall nor as a prime cause; it is a means of grasping a certain dynamic within the social process" $(2005,841)$. It is a normative ideal to which men and women position themselves, rather than a collective description of men. Connell characterises "hegemonic masculinity" as an uneven yet tenacious presence that is implicated in the maintenance of masculine authority and interests across social life.

In terms of recent English prostitution policy, the public consultation Paying the Price (Home Office Communication Directorate 2004) and the resulting Coordinated Prostitution Strategy (Home Office 2006) are notable for the individualised analysis of prostitution adopted by policy writers and makers. For example, these documents focus on women's personal experience of debt, substance misuse or experience of the care system. Recognition and problematisation of the gendered patterning of prostitution are largely absent. Indeed, a review of the history of English prostitution policy from the Contagious Diseases Acts (1864-1869) through to the "prostitute's caution" (1959 Home Office Circular), the introduction of kerb-crawling legislation in the 1980s and the use of Anti-Social Behaviour Orders against street sex workers from the early 2000s suggests that the "problem of prostitution" has traditionally been a problem of managing the women who sell sex and protecting the public from moral harm and nuisance. Men paying for sex off-street, rather than on-street, were largely invisible in policy terms.

The proposal to partly criminalise sex purchase in England and Wales is a recent innovation, representing something of a departure from managing women to focussing on sex buyers, referred to collectively in the policy discourse as "the demand". Criminalisation became politically possible in the late 2000s in part because of increasing international concern about the 
trafficking of human beings for the purpose of exploitation, including exploitation through prostitution, and in part because of some sympathy within senior Labour Government figures that prostitution in certain contexts at least could be understood as violence against women. In November 2007, Conservative MP Philip Hollobone proposed an amendment to the Criminal Justice and Immigration Bill to criminalise paying for sex, which was rejected in committee. In November, the Home Office (2008) published Tackling the Demand for Prostitution: A Review, which recommended criminalising the purchase of sex from an individual who is "controlled for gain”. This was introduced as Clause $13 / 14^{2}$ of the Policing and Crime Bill 2008-2009 and presented to Parliament in December 2008. Clause 13/14 offers an interesting case study because it appears to problematise the purchase of sex (in specific circumstances) and brings the sex buyer (not just the kerb-crawler) in to the policy frame.

\section{Literature review}

In the opening to his book, Reframing Public Policy: Discursive Politics and Deliberative Practices, Fischer states that

Politics and public policy are understood to take shape through socially interpreted understandings, and their meanings and the discourses that circulate them are not of the actors' choosing or making. $(2003,13)$

Fischer's argument is that policymaking is at core a site of discursive struggle over meaning, and that the meanings of discourses are continually negotiated by policy participants rather than fixed according to authorial intent. Fischer $(2003,44)$ challenges traditional policy approaches that focus on institutions or interests because they assume a status independent of the social meanings or discourses that constitute them. However, his discourse approach does not denude the policy process of power because he implies that the competition between discourses in the policy process is an exercise in power:

... [P]olicymaking is a constant discursive struggle over the definitions of problems, the boundaries of categories used to describe them, the criteria for their classification and assessment, and the meanings of ideals that guide particular actions. (Fischer 2003, 60)

${ }^{2}$ In the original Policing and Crime Bill 2008-2009, Clause 13 was concerned with the criminalisation of paying for sex with someone who is "controlled for gain". As the Bill was amended and revised, Clause 13 later became Clause 14 of the Policing and Crime Act 2009. To avoid confusion, I use the term "Clause 13/14" throughout this paper. 
The struggle for shared meaning within policy discourse is, Fischer argues, "even more powerful than money, votes or guns" $(2003,60)$. This reminds us of the cognitive, rather than physically coercive, dimension of power proposed by Gramsci (1971) and Lukes (1974). Discourses "regularise thinking" by offering "basic principles" for action, embedded as they are in our "group collective memory" (Fischer 2003, 75). A good example of this is the common phrase "prostitution is the oldest profession", which has the effect of historicising, normalising, and therefore making inevitable women's participation in prostitution (and, by implication, male sex purchase). Played out within the policy process - in, for example, the making of prostitution policy - discourses may have powerful and material effects.

Freeman (2009) uses the term "translation" to describe this dynamic within the policy process, where meanings are constantly reassigned. Similar to Fischer (2003), Freeman identifies power at the heart of the meaning-making process because "some kinds of association or translation are legitimated and authorised just as others are excluded or denied" (2009, 434). This means that individual policy actors have differential power to change meanings: in Freeman's terms, some translators are "secondary or subservient to an original author" and some are "authors of a new text" $(2009,433)$. Focussing on the differential capacity and influence of policy actors to translate policy enables a more complex account of the workings of power and resistance, because it recognises both the steadfastness of structure and the possibility of agency.

In understanding how the criminalisation policy developed over time, a discursive approach and particularly the notion of "policy translation" offer a promising theoretical model to explore the mechanics of gender and power in the making of prostitution policy. By bringing together the work of Connell and Freeman, this article both contributes to the literature on policy discourse and offers an original approach to evidencing how hegemonic masculinity informs the authoritative version of prostitution policy that emerges. This is centrally important to understanding how relations of power and inequality can both underpin and be reaffirmed in the making of policy.

\section{Methodology}

The defined period for analysing the Parliamentary process was from 1 January 2006, which marked the publication of the Home Office Coordinated Prostitution Strategy, to 12 November 2009, when the Policing and Crime Bill 2008-2009 received Royal Assent. Although Clause 13/14 of the Policing and Crime Bill 2008-2009 constitutes the 
majority of the analysis here, extending the focus on "criminalisation" back to its original appearance within Parliament in 2006 (this was confirmed by online searches of the Parliament archive between 2001 and 2006) better illuminates the journey of the criminalisation policy.

In addition to downloading all the formal documents associated with the Policing and Crime Bill 2008-2009, ${ }^{3}$ Boolean searches of the Parliament website were carried out using 17 selected terms (e.g. "paying for sex"; "prostitution" AND "tackling demand") over the defined period.

All sets of papers were read and edited down to include only the sections relevant to the research. The final data set contained 59 separate documents, amounting collectively to over 500 A4 pages. Using qualitative analysis software, the data were coded by adapting principles from grounded theory (Strauss and Corbin 1990). Given the volume of data, this process started with axial coding, organising the data around five broad headings: Bill wording, Policy responses, Prostitution, Buyers and Sellers. The "Bill Wording" code became the source for the translation analysis and included, for example, all references to the wording of, and amendments to, Clause 13/14.

It is recognised that there are myriad sources and pressures that inform the policy process over a prolonged period. This focus on published Parliamentary activity therefore excludes civil service analysis and advice; it excludes the impact of national pressure groups and corporations, of social and established media, of discussions within Cabinet and within international fora, and to some extent the impact of international policy networks and treaty obligations. Yet, despite published Parliamentary activity being a partial element of the policy process, I hope to demonstrate that it is a rich seam for researchers interested in the unencumbered detail of policymaking, particularly the contribution and interaction of policy actors in that process. Although Parliamentary transcripts are "official documents", they differ from policy documents such as a White Paper in two important ways. First, the transcripts are verbatim (or near verbatim) records of the spoken word. Therefore, this is an analysis of what individual members of Parliament said in the criminalisation debates, rather than their written reflections at the time or a collective statement of policy. An advantage here is that the historic transcript removes a layer of retrospective revision, which current-day interviews with politicians could introduce. It is also tempting to imagine that the individual spoken word will be less shackled by political crafting. A second difference is that formal policy documents tend to promote a singular representation as reality (Fairclough 2001, 256) rather than offering a more fluid, dialogical account.

\footnotetext{
${ }^{3}$ Available from the UK Parliament website at: http://services.parliament.uk/bills/2008-09/ policingandcrime/documents.html and at http://services.parliament.uk/bills/2008-09/policing andcrime/stages.html (12 November 2016).
} 
Drawing on Bakhtin (1986), a dialogical account implies a two-way or multiway exchange of meanings and interpretations. This lack of dialogic in most policy documents is because the traces of countless individual drafting contributions with all their contradictions and inconsistencies are ironed out to form a collective statement. Even where the government is in consultation mode, the text may still be framed by what is politically possible or desirable. The Parliamentary transcripts offer a more unpredictable picture because they draw on a plurality of voices. Further, if we ask different questions and bring different techniques of analysis to that same data set, what I term above as a "multianalysis" approach, this can generate surprising new perspectives and strengthen internal validity.

The translation analysis came to be structured around three key phrases identified through the coding process: (a) strict liability, (b) "controlled for gain" and (c) "force, threats or deception". As the analysis unfolds below, excerpts from selected versions of Clause 13/14 will be reproduced or referenced (to an Online Appendix) to guide the reader and anchor the commentary. Table 1 shows seven proposed amendments to the wording of the criminalisation clause that are considered key moments of change. They are presented in the context of the bill passage through Parliament (Column 1 of the table). It is important to underline that this article is not primarily a legal analysis, rather it explores how definitions (including legal definitions) are used, altered and replaced within the policy discourse and how gender and power may be implicated in that process. ${ }^{4}$

\section{Summary of findings}

\section{Strict liability}

The merit or otherwise of applying strict liability to a criminalisation offence is a key preoccupation in the Parliamentary debates. Strict liability is a legal device that removes the requirement to prove intention, that is that the defendant acted with the intention of committing the offence, as indicated in Section 2(b) of the first reading of Clause 13/14.

It is arguably the part criminalisation of prostitution - the criminalisation of "exploitative" prostitution - that leads Ministers to employ strict liability. This is because the Government fears it will be difficult to prove intention to engage in paying for prostitution involving exploitation, as defendants will claim in their defence that they were unaware of any exploitation. This contrasts with the full criminalisation of all paid sex

\footnotetext{
${ }^{4}$ For the purpose of this paper, I adopt Birkland's definition of "policy" as a statement of proposed action (Birkland 2001,9) and I define "law" as the formal codification of that statement and its entry into a legal framework.
} 
Table 1. Selected proposed wording used for the translation analysis

\begin{tabular}{|c|c|c|c|}
\hline Bill stage & Date & Description & Status \\
\hline House of Commons Committee Stage & 27 November 2007 & $\begin{array}{l}\text { Proposed Clause } 8 \text {, Criminalising the purchase } \\
\text { of sexual services, Criminal Justice and } \\
\text { Immigration Bill Committee }\end{array}$ & $\begin{array}{l}\text { New clause proposed by MP Philip Hollobone to the } \\
\text { Criminal Justice and Immigration Bill Committee, and } \\
\text { subsequently rejected }\end{array}$ \\
\hline House of Commons First Reading & 18 December 2008 & $\begin{array}{l}\text { First reading of the Policing and Crime Bill } \\
\text { 2008-2009 }\end{array}$ & $\begin{array}{l}\text { First iteration by the Government of Clause } 13 / 14 \text {, } \\
\text { "Paying for sexual services of a controlled prostitute: } \\
\text { England and Wales" }\end{array}$ \\
\hline House of Commons Committee Stage & 16 April 2009 & $\begin{array}{l}\text { Human Rights Justice Committee Legislative } \\
\text { Scrutiny Policing and Crime Bill }\end{array}$ & $\begin{array}{l}\text { Comments on Clause } 13 / 14 \text { suggested by the HRJC and } \\
\text { proposed revised format }\end{array}$ \\
\hline House of Commons Report Stage & 19 May 2009 & $\begin{array}{l}\text { Report Stage House of Commons, proposed new } \\
\quad \text { Clause } 25\end{array}$ & $\begin{array}{l}\text { New clause } 25 \text { "Paying for sexual services of a prostitute } \\
\text { known to be trafficked or coerced: England and } \\
\text { Wales", suggested by Evan Harris MP and others to } \\
\text { replace Clause 13/14 }\end{array}$ \\
\hline House of Commons Report Stage & 19 May 2009 & $\begin{array}{l}\text { Report Stage House of Commons, Amendment } \\
211\end{array}$ & $\begin{array}{l}\text { New form of words for Clause } 13 / 14 \text { tabled by Anthony } \\
\text { Steen MP }\end{array}$ \\
\hline House of Lords First Reading & 21 May 2009 & $\begin{array}{l}\text { House of Lords Bill 48, as brought from the } \\
\text { House of Commons on } 20 \text { May }\end{array}$ & $\begin{array}{l}\text { Clause } 13 / 14 \text { in its revised format following } \\
\text { consideration by the House of Commons. The } \\
\text { Policing and Crime Bill } 2008-2009 \text {, or "Bill } 48 \text { " as it } \\
\text { is termed, is now presented to House of Lords for } \\
\text { consideration }\end{array}$ \\
\hline House of Lords Committee Stage & 21 October 2009 & $\begin{array}{l}\text { Bill as amended in the House of Lords } \\
\text { Committee }\end{array}$ & $\begin{array}{l}\text { Clause } 13 / 14 \text { in its revised format following } \\
\text { consideration in the House of Lords. There are no } \\
\text { further changes to Policing and Crime Bill before } \\
\text { receiving Royal Assent and so this version becomes } \\
\text { the final "authoritative" wording for Clause } 14 \text { of the } \\
\text { Policing and Crime Act } 2009 \text {, "Paying for sexual } \\
\text { services of a prostitute subjected to force etc." }\end{array}$ \\
\hline
\end{tabular}

\section{Immigration Bill Committee}

2008-2009

Human Rights Justice Committee Legislative

Scrutiny Policing and Crime Bill

port Stage House of Commons, proposed new

Report Stage House of Commons, Amendment

House of Commons on 20 May
House of Lords Bill 48, as brought 
After section 53 of the Sexual Offences Act 2003 (c. 42) insert-

'53A Paying for sexual services of a prostitute controlled for gain

(1) A person (A) commits an offence if-

(a) A makes or promises payment for the sexual services of a prostitute (B), and

(b) any of B's activities relating to the provision of those services are intentionally controlled for gain by a third person $(C)$.

(2) The following are irrelevant-

(a) where in the world the sexual services are to be provided and whether those services are provided,

(b) whether A is, or ought to be, aware that any of B's activities are controlled for gain.

(3) An activity is "controlled for gain" by $C$ if it is controlled by $C$ for or in the expectation of gain for $\mathrm{C}$ or another person (apart from $\mathrm{A}$ or $\mathrm{B}$ ).

(4) A person guilty of an offence under this section is liable on summary conviction to a fine not exceeding Level 3 on the standard scale.'

(Commons Hansard, 18 Dec 2008, col. 1262) [emphasis added]

Figure 1 House of Commons First Reading of the Policing and Crime Bill 2008-2009, 18 December 2008.

proposed by Philip Hollobone in the 2007 Criminal Justice and Immigration Bill, which requires intention or mens rea: "A person (A) commits an offence if he intentionally obtains for himself the sexual services of another person (B), and before obtaining those services, he has made or promised payment for those services to $\mathrm{B}$ or a third person, or knows that another person has made or promised such a payment" (see Online Appendix for Figure 1A). ${ }^{5}$ Critics of Clause 13/14 argue that applying strict liability is unfair because the sex buyer may have no way of knowing for certain whether a woman is exploited. Some indeed argue that removing intention may diminish the responsibility of those who knowingly have sex with exploited women, because they will be prosecuted irrespective of intention (see e.g. Lord Faulkner, Lords Hansard, 3 June 2009, col. 273).

${ }^{5}$ Col 539. Great Britain, House of Commons Public Bill Committee Debates (27 November 2007), Criminal Justice and Immigration Bill Committee, vol. n/a, cols. 539-568, http://www. publications.parliament.uk/pa/cm/cmpbcriminal.htm (accessed 12 November 2016). 
A number of attempts are made by critics of Clause 13/14 to introduce a recklessness test. The legal meanings and varying use of the term "recklessness" are complex (for a commentary, see Ashworth 2009, 177-182), but of most relevance here it means "the accused had foreseen that the particular kind of harm might be done and yet has gone on to take the risk of it" (Ashworth 2009, 178). In terms of Clause 13/14, this requires that prosecutors demonstrate that the buyer should have known that a woman was exploited and should have desisted accordingly. The first attempt to recognise recklessness is made in April 2009 by the Human Rights and Justice Committee who introduce the phrase "aware, or ought to be aware" in Sections $(1)(c)$ and $(1 \mathrm{~A})$ of their revision. In this proposal, it is an offence for person (A) to make or promise to make payment for the sexual services of a prostitute (B) if they are aware or ought to be aware that person B is controlled for gain. "Ought to have" knowledge is defined as a judgement "having regard to all the circumstances, including any steps A has taken to ascertain whether B is controlled for gain" (see Online Appendix Figure 1B). ${ }^{6}$ At the Bill Report Stage in May 2009, a new clause recognising recklessness is sponsored by Evan Harris (Liberal Democrat), Lynne Jones (Labour) and John McDonnell (Labour). The amendment sponsors use a similar formula of "knows, or ought to know" (see Online Appendix Figure 1C), ${ }^{7}$ although a test for "ought to know" is not provided in this proposal.

Amendment 25 is subject to a House of Commons vote on 19 May 2009 and defeated by 285 votes to 201. In the 2 nd sitting of the House of Lords Committee on 1 July 2009, Liberal Democrat Peer Baroness Miller of Chilthorne Domer sponsors an identical form of words (Lords Amendment 45 ) to the Commons Amendment 25, which is subsequently withdrawn. Concerns raised by Government in opposition to the recklessness amendments focus particularly on their enforceability. The proposed tariff for new Clause 25 is noticeably higher, with a fine and up to six months imprisonment for a summary conviction and up to 14 years imprisonment for a conviction on indictment. ${ }^{8}$

${ }^{6}$ Para 1.36. Great Britain, Joint Select Committees (16 April 2009) Human Rights Joint Committee Tenth Report, Legislative Scrutiny: Policing and Crime Bill, http://www.publications. parliament.uk/pa/jt200809/jtselect/jtrights/68/6802.htm (accessed 12 November 2016).

7 Col. 1398. Great Britain, House of Commons Hansard Parliamentary Debates (19 May 2009) Policing and Crime Bill Debate, vol. 492, cols. 1398-1471, http://www.publications.parliament.uk/ $\mathrm{pa} / \mathrm{cm} 200809 / \mathrm{cmhansrd} / \mathrm{cm} 090519 / \mathrm{debindx} / 90519-x . h t m$ (accessed 12 November 2016).

${ }^{8}$ In England and Wales, a "summary trial" would be dealt with in a magistrates' court and a "conviction on indictment" would occur where a defendant is tried by jury in a Crown Court (which is a higher court, with greater sentencing powers). A defendant may elect for trial by jury or it may be recommended by the magistrate, if the magistrate feels that the seriousness of the offence exceeds the sentencing powers afforded to the magistrates' court. 


\section{"Controlled for gain" and "Force, threats or deception"}

The first draft of Clause 13/14 (see Figure 1) makes clear that for the offence to apply the provision of sexual services by an individual must be "intentionally controlled for gain by a third person". The use of the phrase "controlled for gain" provokes a number of objections. First, it is argued that the lack of clarity over the definition of "controlled" makes the phrase so elastic as to criminalise "innocent" individuals, such as a reception maid or "madam". Second, there is some debate as to why financial gain is a necessary element in identifying exploitation.

However, by the Bill Report Stage on 20 May 2009, the Government has conceded to the arguments over "controlled for gain" and offers a new form of words requiring that the prostitute involved must have been subject to "force, deception or threats". In other words, the offence has been narrowed significantly to focus not just on women who are controlled for gain (or "pimped", in common parlance), but also on women who are both controlled for gain and subject to some form of physical or psychological compulsion (see Online Appendix Figure 1D). ${ }^{9}$ The phrase "force, deception or threats" is presented as further clarifying in what circumstances prostitution becomes "exploitative" prostitution and the reference to nonphysical force is notable. Although the Government rejects amendments by Lynne Jones (Labour) and others to introduce the word "coercion" in Clause 13/14, citing its imprecision (Commons Hansard, 19 May 2009, col. 1402), Ministers do recognise that psychological pressure is an important factor in understanding the control of women in prostitution.

A number of Parliamentary speakers are concerned about the role of drug use and drug supply by pimps in the control of women (e.g. John Gummer, Commons Hansard, 19 May 2009, col. 1407). Clause 25 sponsored by Liberal Democrat Evan Harris and two Labour members makes specific reference to a situation where an individual "provided sexual services in order to gain access to controlled drugs" (see Online Appendix Figure 1C). The Government, however, argues that such a situation is already covered under Clause 13/14, and that such an amendment would not distinguish between recreational users and women controlled by drug use (Lord Brett, Lords Hansard, 1 July 2009, col. 252). Specific reference in Clause 13/14 to control through drug use is therefore rejected.

During the Bill Report Stage in the House of Commons on 19 May 2009, there are two attempts to make specific reference to trafficking within Clause 13/14. The first is the new Clause 25 sponsored by Liberal

${ }^{9}$ Great Britain, House of Lords Bill (21 May 2009) Bill 48 "Policing and Crime Bill" as brought from the House of Commons on 20 May 2009, http://www.publications.parliament.uk/ pa/ld200809/ldbills/048/09048.i-v.html (accessed 12 November 2016). 
14 Paying for sexual services of a prostitute subjected to force etc: England and Wales

After section 53 of the Sexual Offences Act 2003 (c. 42) insert-

"53A Paying for sexual services of a prostitute subjected to force etc.

(1) A person (A) commits an offence if-

(a) A makes or promises payment for the sexual services of a prostitute (B),

(b) a third person (C) has engaged in exploitative conduct of a kind likely to induce or encourage $B$ to provide the sexual services for which $A$ has made or promised payment, and (c) $C$ engaged in that conduct for or in the expectation of gain for $C$ or another person (apart from $A$ or $B)$.

(2) The following are irrelevant-

(a) where in the world the sexual services are to be provided and whether those services are provided,

(b) whether $\mathrm{A}$ is, or ought to be, aware that $\mathrm{C}$ has engaged in exploitative conduct.

(3) $\mathrm{C}$ engages in exploitative conduct if-

(a) C uses force, threats (whether or not relating to violence) or any other form of coercion, or

(b) C practises any form of deception.

(4) A person guilty of an offence under this section is liable on summary conviction to a fine not exceeding Level 3 on the standard scale."

$[\ldots]$

(House of Lords, 21 Oct 2009, Bill 74) [emphasis added]

Figure 2 Policing and Crime Bill as amended in the House of Lords Bill Committee, 21 October 2009.

Democrat Evan Harris and others (see Online Appendix Figure 1C), which specifically includes the Palermo Declaration definition of trafficking. ${ }^{10}$

10 The Protocol to Prevent, Suppress and Punish Trafficking in Persons, especially Women and Children is a protocol to the Convention against Transnational Organised Crime, itself one of the two protocols adopted by the United Nations in Palermo, Italy, in 2000. Ratifying the trafficking protocol commits states to prevent and combat trafficking in persons, to protect and assist victims of trafficking and to promote cooperation between states to achieve these objectives internationally. 
Similarly, Anthony Steen tables Amendment 211 on 19 May 2009 to refer only to a "trafficked prostitute" (see Online Appendix Figure 1E). ${ }^{11}$ The Government is, however, concerned to recognise exploitation more broadly:

Lord Brett (Labour): I take on board the noble Lord's point as requested. "Trafficked" in that sentence is shorthand. In the clause we are looking at "coercion" and "trafficked" as a group, not simply at those who have been subject to trafficking. (Lords Hansard, 1 July 2009, col. 270)

By October 2009, the phrase "force, threats or deception" has been moved to part 3 of Clause 13 - now Clause 14 - to define the new choice of words "engaged in exploitative conduct", as amended in the House of Lords.

\section{Discussion}

Having set out three threads of the translation history of criminalisation strict liability, controlled for gain, and force, threats or deception - I argue that there are two key areas of contention driving the translation of prostitution policy here: defining responsibility and defining exploitation. I will demonstrate how gender and power are implicated in each definition.

\section{Strict liability: defining responsibility}

The First Reading of Clause 13/14 (18 December 2008, see Figure 1) presents a form of selective criminalisation that attempts to attribute some responsibility to the sex buyer for exploitation within prostitution. Not only does it attribute responsibility but by employing strict liability it also removes the defence of ignorance or lack of intention. This is a notable break with past policy in this area (see above), because it brings buyers into the spotlight and problematises the purchase of sex itself, rather than the location or implications for public decency. It also demonstrates the uneven yet tenacious influence of hegemonic masculinity: on the one hand, Clause 13/14 appears to undermine the naturalness of male sex purchase by identifying a criminal offence; however, on the other hand, by focussing on exploitation, it implies that prostitution in general is acceptable and non-exploitative.

The Protocol definition of trafficking is available at: https://www.unodc.org/documents/treaties/ UNTOC/Publications/TOC\%20Convention/TOCebook-e.pdf (12 November 2016).

${ }^{11}$ Col 1399. Great Britain, House of Commons Hansard Parliamentary Debates (19 May 2009), Policing and Crime Bill Debate, vol. 492, cols. 1398-1471, http://www.publications.parliament.uk/ $\mathrm{pa} / \mathrm{cm} 200809 / \mathrm{cmhansrd} / \mathrm{cm} 090519 / \mathrm{debindx} / 90519$-x.htm (accessed 12 November 2016). 
Within the Parliamentary debates, there is resistance both to the responsibilisation of buyers in principle and also specifically to the "net-widening" effect of strict liability, as it is argued that all sex buyers are placed on alert (Home Office Under-Secretary of State Alan Campbell identifies this implied policy aim: see Commons Hansard, 19 May 2009, col. 1410). Some speakers claim that strict liability actually weakens responsibility because there is no credit given if the intention had been good - although this paints a rather diminished picture of sex buyers, who surely have a moral obligation to establish exploitation, whether the legal obligation exists or not. Indeed, this suggests the limitations of legal compliance without wider attitudinal change.

Attempts are made by the Human Rights Joint Committee (16 April 2009, see Online Appendix Figure 1B) and Liberal Democrat MPs Evan Harris and Paul Holmes (19 May 2009, see Online Appendix Figure 1C) to moderate this blanket responsibility by proposing instead an offence of recklessness. This would require a judgement on whether the buyer ought to have been aware that the seller was controlled and/or forced and allows space for a defence case to be built. However, what is interesting here is that new Clause 25 also recommends a tariff on summary conviction of a fine and up to six months of imprisonment, and on conviction on indictment up to 14 years imprisonment. This is substantially higher than the maximum penalty available under Clause $13 / 14$, which is a fine on summary conviction not exceeding Level 3 on the standard scale - around $£ 1,000$. Therefore, although the recklessness offence may be harder to prosecute than a strict liability offence, because it requires proof of "ought to have knowledge", it also has a maximum tariff that appears to signal more strongly the gravity of the offence and the increased responsibility of the buyer. This again illustrates the knotty dynamic of hegemonic masculinity; although on the one hand the revised Clause 13/14 appears to signal strong censure, the circumstances in which men will actually be held to account are significantly narrowed.

In general, the gendered patterning of prostitution is not problematised by the speakers in Parliament. This is taken-for-granted knowledge, consistent with the prevailing understanding of gender relations. Rather, the policy problem is constructed as whether and how to apportion responsibility to the buyer in cases where the individuals whom they pay for sex are "exploited" (also a contested term: see discussion below). Considerable Parliamentary discussion is devoted to considering first whether sex buyers are exploiters or simply honest consumers buying at the end of a supply chain for which they cannot be accountable. In response, it could be argued that, unlike buying a carpet made by a child labourer from overseas, sex buyers are paying for "embodied labour" (Anderson and O'Connell Davidson 2003, 25), in which case we might expect buyers to be somewhat cognisant to the circumstances of the "seller". 
Second, some speakers are concerned that Clause 13/14 will criminalise the "good" or "harmless" buyers who may be allies for women in reporting exploitation, although evidence for this is not provided within the debates. The "working class" man and the "widower" are specific examples of "good" punters mentioned, belying an interesting insight in to the assumptions of members of Parliament. The suggestion is that sex purchase is the reserve of men who experience some social "disadvantage", be that economic status, disability, age, education or lack of confidence. Yet, surveys of sex buyers suggest an everyman demographic - an ethnic class, marital status and education profile consistent with the local region (Brooks-Gordon and Gelsthorpe 2003; Coy et al. 2007; Macleod et al. 2008; Farley et al. 2009 in the United Kingdom (UK); Lowman and Atchison 2006 in Canada; Træen et al. 2005 in Norway; Chen 2003 in Taiwan; Månsson 2004 in Sweden; Monto and McRee 2005 in the United States).

Finally, there is some discussion on the distinction between paying for sex with someone who is forced and rape. This is well illustrated by Conservative MP Charles Walker when the Criminal Justice and Immigration Bill Committee in 2007 are considering a proposed amendment by Conservative MP Philip Hollobone to criminalise sex purchase (Commons Hansard, 27 November 2007, col. 552). Walker is concerned whether those forced into prostitution can rightly be considered to have given consent to sex, and therefore whether buyers may actually have committed rape. $\mathrm{He}$ is interrupted by Committee Chair Nicholas Winterton (Commons Hansard, 27 November 2007, col. 551) who directs that the clause in discussion is on prostitution and not rape. Elsewhere in the debates, speakers consider the prospects of a rape conviction within the context of prostitution as near impossible (Commons Hansard, 29 January 2009, col.110; Lords Hansard, 1 July 2009, col. 268; Lords Hansard, 3 June 2009, col. 273; Commons Hansard, 19 May 2009, col. 1405), a view that speaks to the assumption that payment affords buyers unlimited "powers of command" over a woman's body (O'Connell Davidson 1998, 9), consistent with hegemonic masculinity.

It has proved particularly difficult to prosecute rape when it occurs in a setting where a women has entered voluntarily or where there have previously been consensual sexual relations (e.g. she is at home with her partner or she is on a date); indeed, rape within marriage only became an offence in England and Wales in 1991. Applying a gender analysis, this suggests that a woman is believed to "sign over" her rights to resist sexual advances, because by virtue of "being there" (entering marriage, entering a man's home after a date) she is implicitly consenting. This perception applies in extremis to women in prostitution: if their "role" is to sell sex, 
how can they withdraw consent? Women in prostitution are also deemed unreliable witnesses, as Sullivan recounts:

In common law jurisdictions like the United Kingdom, Australia, New Zealand and Canada, some of the evidentiary jurisprudence clearly linked chastity with veracity. So women who were or had been sex workers, those who were "rumoured" to be prostitutes or who were simply promiscuous and behaving "like a prostitute" lacked credibility as complainants [...] Men accused of sexual assault were therefore able to use evidence of prostitution to defend themselves, to undermine the credibility of rape complainants and to successfully avoid conviction. $(2007,128)$

It is interesting to note briefly that the "unreliability" of women as witnesses is raised in the debates about the enforcement of Clause 13/4 (see e.g. Keith Vaz MP, Commons Hansard, 19 January 2009, col. 536). Vaz and other speakers are concerned that sex buyers will be unfairly prosecuted because women may lie about whether they are forced into prostitution.

Despite sustained criticism of strict liability, it survives the translation journey and emerges intact from the House of Lords committee process on 21 October 2009. If the use of strict liability serves to responsibilise and actively prosecute buyers for purchasing sex in circumstances of exploitation, then its endurance through the translation process could be said to challenge the exercise of hegemonic masculinity. Yet, the circumstances in which it applies are narrowed further. This reveals the complexity of tracking the translation process: as the journey of one thread is established in this case "strict liability" - two accompanying threads are changing "controlled for gain" and "force, threats or deception" - which impact the meaning overall.

\section{"Controlled for gain" and "force, threats or deception": defining exploitation}

Defining in what circumstances prostitution is exploitative occupies a considerable proportion of the parliamentary debates on criminalisation. There is disagreement, for example, between those who want to broaden the scope of the legislation by keeping the language flexible and those who want to narrow the focus by stating explicitly what is meant by exploitation.

In the first reading of Clause 13/14 (see Figure 1), it is an offence to pay (or attempt to pay) for sexual services with someone who is "controlled for gain". There is concern first that the definition of "controlled" lacks clarity, and second that there is some debate as to why financial gain is a necessary element in identifying exploitation. On the question of gain, the Government clearly has international obligations in mind (including the 
2000 "Palermo" Protocol to Prevent, Suppress and Punish Trafficking in Persons which the UK ratified in 2006, see footnote 10) and believes that the demand from British sex buyers and the profit to be made from each individual selling sex are significant drivers of human trafficking. In practical terms too, it is hard to envisage a situation where gain (whether financial or in lieu of drugs, for example) would not be a key motivation in the organisation of prostitution. For some speakers, the concern to foreground harm and de-problematise financial gain is consistent with their support for the legal regulation of prostitution.

The Government does concede to the arguments about the wide reach of "controlled for gain" and the concern to define "control". In seeking a definition, Conservative backbencher Anthony Steen proposes that Clause 13/14 applies only to trafficked women (see Online Appendix Figure 1E), and a replacement clause sponsored by Evan Harris suggests specific reference to drug use and to trafficking (see Online Appendix Figure 1C). The Government is reluctant to use such specific wording, partly because proving such contexts may require an extra level of evidence, including victim testimony. Instead, ministers require only that a controlling third party be identified, where "controlling" is identified as subjecting the prostitute to "force, threats or deception" (see Online Appendix Figure 1D).

Although there is much disquiet among speakers about the strict liability element of Clause 13/14, the fact that charges can only be brought against a buyer if a third person who is "controlling for gain" or "engaging in exploitative conduct" is identified is barely noted by either supporters or critics of the policy. This requirement to identify a third party means that Clause 13/14 can only be prosecuted in very limited circumstances such as during a brothel raid where the pimps/controllers are also known and prosecuted and where the police can prove that the individuals identified as buyers on the premises were indeed attempting to pay for sexual services. ${ }^{12}$ Therefore, even under the broader version of Clause 13/14 set out in the First Reading (see Figure 1), the practicalities of charging are difficult. The Crown Prosecution Service guidance on Clause 13/14 in its final form says that the legislation is only likely to be used in off-street settings because prosecutors would use existing kerb-crawling legislation in street settings, "as this does not require proof of exploitative conduct". ${ }^{13}$

12 This insight came after I met with the Avon and Somerset Police Vice team based at Bristol Trinity Police Station in 2011. As part of the groundwork for this research, I met the team to discuss Clause 13/14 and what it meant for their work.

${ }^{13}$ Crown Prosecution Service Legal Guidance on Prostitution and the Exploitation of Prostitution, Paying for Sexual Services: Charging Practice. http://www.cps.gov.uk/legal/p_to_r/ prostitution_and_exploitation_of_prostitution/\#a15 (12 November 2016). 
I would argue that defining exploitation in relation to a third-party perpetrator largely neglects the situational and structural enablers of prostitution. For example, Clause 13/14 as drafted makes it acceptable to pay for sex with a heroin-addicted street worker if she is buying drugs for herself, but not if she works for her boyfriend and pimp who acts as her "security" and also exchanges her earnings for drugs. Yet, it could be argued that paying for sex with the woman in the first situation is at least as exploitative as paying for sex with the woman in the second situation; in both cases, the buyer is benefiting from the desperation generated by addiction and withdrawal and is instrumental in perpetuating the seller's drug addiction. Defining exploitation in terms of identifiable victims and perpetrators obscures the way in which exploitation is an outcome and abuse of power. It could be argued that where prostitution is embedded in relations of gender inequality (and other inequalities), it is inherently exploitative. The failure of policymakers to wrestle with this in the development of policy both reflects and reinforces the operation of hegemonic masculinity.

A further effect of policymakers understanding the "problem of prostitution" in individual rather than structural terms is that it tends to coalesce discussions narrowly around choice/lack of choice. The modern preoccupation with, and conceptualisation of, individual choice and freedom is inherited from the white, male, middle-class thinkers of the Enlightenment (see Harding 1996, for a fuller discussion). Commonly, the distinction between freedom and unfreedom is not so fine: indeed, it can be hard to unpick how relations of gender (intersecting other relations of ethnicity, income, immigration status and so on) can structure agency. This is not to say that criminal responsibilisation of sex buyers may not be a worthwhile policy tool, and indeed symbolic law can "lead" public attitudes: but it needs surely to be in the context of broader social policy change, animated by principles of gender equality and social justice.

Finally, it is important to acknowledge the challenge of grasping the dynamic of hegemonic masculinity. It could be argued that gender relations are irrelevant in explaining the resistance within Parliament to introducing full or part criminalisation for sex purchase. This resistance could simply reflect concern about the particular formula of criminalisation (the targeting of the buyer or the practical enforcement, for example) or indeed the appropriateness and implications of using criminal law in this context. However, the red herring here is focussing on the intention of individual policymakers rather than the outcome of structures. As Jenkins astutely identifies:

... [P]olicy formulation and implementation often, whether explicitly or implicitly, identifies and defines human beings, and the relationships that 
ought to exist between them - as populations, as groups, as categories of individuals, or as individuals - in ways that are necessarily consequential, even if those consequences may be unintended. (Jenkins 2007, 29, summarising Clarke, 2004, emphasis added)

The starting point for this work is that the policy translation process is not arbitrary but is rather the outcome of discursive processes of legitimation and exclusion (Freeman 2009). Rather than try to elucidate individual intention, it is argued here that we focus on what ideological work is accomplished by the policy that emerges as authoritative. In this way, we can consider how the meanings of policy may be complicit with hegemonic masculinity (see Connell and Messerschmidt 2005, 5), without being drawn into often unresolvable arguments about individual motivation or direct cause and effect.

In summary, the narrowing of Clause 13/14 through the policy translation process in the definitions of "responsibility" and "exploitation" serves to redefine the boundaries of acceptable male sex purchase (Skilbrei 2012, 252) while leaving the practice of prostitution broadly intact. It does not problematise the gendered patterning of prostitution: this is a given. As such, it could be argued that hegemonic masculinity is implicated in the making of prostitution policy.

Although the focus of this work is on the translation of policy within Parliament, it can be noted that in a written response to a Parliamentary question from Shadow Home Affairs Minister Helen Jones MP, Attorney General Oliver Heald reported in the House of Commons in December 2013 that in 2010-2011 40 charges had been brought under Section 14 of the Policing and Crime Act 2009 and reached a first hearing. This figure was just 7 for 2011-2012 and 8 for 2012-2013 (Commons Hansard, 2 December 2013, C533W). Oliver Heald noted that these figures were held by the Crown Prosecution Service, and claimed that figures for arrests and convictions under the offence were not available. In October 2015, Gavin Shuker MP reported in the House of Commons that since 2013 there have been twice the prosecutions for soliciting and loitering than for profiting from prostitution and kerb-crawling:

... [I]n the 2014-15 figures, with 227 charges for kerb crawling reaching court compared with 456 prosecutions initiated against people selling sex. Just 83 prosecutions for control of prostitution-pimping-were brought in the same year. Those figures refer to men and women on the same streets, and it takes a particular kind of liberal delusion to be convinced that prostitution is caused by a surge of women wishing to sell sex rather than by men wishing to purchase it. Yet it is women who sell sex who are targeted in our law courts, not the men who create the demand in the first place. (Commons Hansard, 13 October 2015, C58WH). 
Further research is needed to explore how gender and power (and other factors) are implicated in the way that prostitution policy is translated through implementation, to understand how and why these patterns emerge.

\section{Conclusions}

Drawing on the concepts of "hegemonic masculinity" (Connell 1987; with Messerschmidt 2005) and "policy translation" (Freeman 2009) and using the criminalisation of sex purchase as a case study, I have attempted in this article to elucidate how gender and power operate in the making of English prostitution policy. By tracing the development and deployment of three phrases in particular (strict liability; "controlled for gain" and "force threats or deception") as Clause 13/14 moves through each Bill stage, I highlighted the contested understandings of "responsibility" and "exploitation" in relation to sex buyers and to the practice of prostitution broadly.

My analysis suggests that many members of Parliament were reluctant to attribute criminal responsibility for exploitation to buyers because they felt it disproportionate and possibly unfair, given also the use of a strict liability approach. Moreover, a number of speakers who expressed concern about the net-widening effect of "controlled for gain" were keen to supplement this phrase with an acute interpretation of "exploitation", involving evidence of trafficking, drug use or force, for example. Such interventions signal the speakers' acceptance of (or at least acquiescence in) prostitution in general and assume a clear boundary between choice and coercion, exploitative and non-exploitative. The version of Clause 13/14 that emerges from the translation process (see Figures 1, 2, for comparison) is therefore narrower in application and serves only to redraw the boundaries of acceptable male sex purchase. It is for this reason that I argue hegemonic masculinity both informs and is reaffirmed by the policy-making process.

I also want to reflect in this concluding section on the value of attempting to trace the translation of policy. To recap, the findings presented in this article were one strand of a "multianalysis" approach, where different analytical techniques were applied to the same set of Parliamentary data. The multianalysis approach developed for this wider research was in part an outcome of taking a single method (documentary analysis) to analyse a single case study (criminalisation) with a single theoretical lens (gender and power). Rather than broadening the analysis by adopting an intersectional approach, for example, or supplementing the documentary data with interviews, I pursued the analysis in depth. That analytical depth was achieved by reinterpreting the same data through different analytical 
perspectives, prompted by different questions. This included considering how gender and power were implicated in who spoke on criminalisation (through analysing the substance of speakers' contributions by gender, for example) and in what they said (through both a thematic analysis and a critical discourse analysis).

Charting the unfolding process of meaning-making is no easy task. Although it is possible to describe the particular frames of reference or adopted definitions that policymakers use (as in a thematic analysis) or to isolate and explore a particular discourse and its implications (as in a critical discourse analysis), it is hard to harness those snapshots into a moving picture that illuminates policy change.

Freeman (2009) uses the term "translation" to describe this dynamic within the policy process, where meanings are constantly reassigned. $\mathrm{He}$ identifies power at the heart of the meaning-making process because "some kinds of representation and association are legitimated and authorised just as others are excluded or denied" (Freeman 2009, 434; see also Fischer 2003). There are a number of issues with trying to apply practically this theoretical proposal, which it should be noted is not required by the authors. First, we need to identify a particular strand (or strands) of meaning and follow this between two particular points in time - making decisions, for example, on what constitutes a significant change in meaning and indeed what constitutes the same strand of meaning. Yet, policy meanings are multiple and interweaving, forking and branching. In addition, the policy process is open both in time (e.g. how far back do we identify the evolution of a policy and at what point can we say its translation is complete?) and in time and space (policy actors are introducing influences from multiple sources, both concurrent and past). In addition, what defines the record of policy meanings is open to interpretation: here I have selected amendments in the formal wording of proposed clauses on criminalisation. However, the translation process is also documented in the relevant minutes, emails and briefing papers within the Home Office, in the media reports on criminalisation, and in the conversations between policy actors both on and off the record. Therefore, although in Freeman's theoretical conception translation is fluid and embracing, in practical application the requirements of method and manageability require boundaries to be established. Inevitably then, some of the complexity and authenticity of translation are lost in trying to elucidate its operation.

If we accept that the policy translation process is not arbitrary but is rather the outcome of processes of legitimation and exclusion, then the further challenge is evidencing how power relations are implicated in policy change. The cognitive and hegemonic dimensions of power, as outlined by Gramsci (1971), Lukes (1974), Connell (1987), Fischer (2003) and 
others, make this difficult but important work. Further research is needed to explore whether similar findings would apply to other prostitution policy proposals in the English context. Parliamentary data offer fertile ground to apply translation analysis to consider, for example, heteronormativity and the passage of the Marriage (Same Sex Couples) Act 2013 or a number of intersections of identity and power within the Equality Bill (2009-2010). In addition, work is required to understand how policy is translated in implementation, including how front-line bureaucrats (Lipsky 1980) negotiate meanings and how gender and power relations inform practice.

In summary, by tracing the translation of policy through key moments of change, we can explore how particular meanings are legitimated or excluded, shaping the final version of policy that emerges as authoritative. Given the material implications for different groups in society, it is critical that we pay attention to how relations of power both inform and are consolidated within the policy process.

\section{Acknowledgement}

This work was funded by a $\mathrm{PhD}$ research studentship awarded by the UK Economic and Social Research Council (ESRC).

\section{Supplementary material}

To view supplementary material for this article, please visit https://doi.org/ $10.1017 /$ S0143814X16000295

\section{References}

Anderson B. and O'Connell Davidson J. (2003) Is Trafficking in Human Beings Demand Driven? A Multi Country Pilot Study. International Organisation for Migration, Geneva, https://www.compas.ox.ac.uk/media/ER-2004-Trafficking_Demand_Driven_IOM.pdf (accessed 12 November 2016).

Ashworth A. (2009) Principles of Criminal Law. Oxford: Oxford University Press.

Bakhtin M. M. (2004 [1986]) Speech Genres and Other Late Essays. Austin, TX: University of Texas Press.

Birkland T. A. (2001) An Introduction to the Policy Process. New York: M.E. Sharpe Inc.

Brooks-Gordon B. and Gelsthorpe L. (2003) What Men Say When Apprehended for KerbCrawling: A Model of Prostitutes Clients Talk. Psychology, Crime \& Law 9(2): 145-171.

Chen M. H. (2003) Contradictory Male Sexual Desires - Masculinity Lifestyles and Sexuality Among Prostitutes Clients in Taiwan. Travail, Genre et Societes 10: 107-128.

Connell R. (1987) Gender and Power: Society, the Person and Sexual Politics. Cambridge: Polity Press.

Connell R. and Messerschmidt J. W. (2005) Hegemonic Masculinity: Rethinking the Concept. Gender and Society 19(6): 829-859. 
Coy M., Horvath M. and Kelly L. (2007) “It's Just Like Going to the Supermarket”: Men Buying Sex in East London. Report for Safe Exit, Child and Woman Abuse Studies Unit, London Metropolitan University, London, http://embracedignity.org/uploads/DemandReport READ.PDF (accessed 12 November 2016).

Fairclough N. (2001) The Discourse of New Labour: Critical Discourse Analysis. In Wetherell M., Taylor S. and Yates S. J. (eds.), Discourse as Data: A Guide for Analysis. London: Sage Publications in Association with the Open University, 229-266.

Farley M., Bindel J. and Golding J. M. (2009) Men Who Buy Sex: Who They Buy and What They Know. Eaves Project, London, http://i1.cmsfiles.com/eaves/2012/04/MenWhoBuySex89396b.pdf (accessed 12 November 2016).

Fischer F. (2003) Reframing Public Policy: Discursive Policies and Deliberative Practices. Oxford: Oxford University Press.

Freeman R. (2009) What is "Translation"? Evidence and Policy 5(4): 429-447.

Gramsci A. F. (1971) Selections from the Prison Notebooks. New York: International Publishers.

Harding S. G. (1996) Feminism, Science and the Anti-Enlightenment Critiques. In Garry A. and Pearsall M. (eds.), Women, Knowledge, and Reality: Explorations in Feminist Philosophy. Chapter 16. London: Routledge, 298-320.

Home Office (2006) A Coordinated Prostitution Strategy. London: Home Office.

Home Office (2008) Tackling the Demand for Prostitution: A Review. London: Home Office.

Home Office Communication Directorate (2004) Paying the Price: A Consultation Paper on Prostitution. Home Office Communication Directorate, London, http://webarchive. nationalarchives.gov.uk/+/http://www.homeoffice.gov.uk/documents/paying_the_price.pdf (accessed 12 November 2016).

Jenkins R. (2007) The Meaning of Policy/Policy as Meaning. In Hodgson S. M. and Irving Z. (eds.), Policy Reconsidered: Meanings, Politics and Practices. Chapter 2. Bristol, UK: The Policy Press, 21-36.

Kelly L., Coy M. and Davenport R. (2009) Shifting Sands: A Comparison of Prostitution Regimes Across Nine Countries. Child \& Woman Abuse Studies Unit, London Metropolitan University, London, http://myweb.dal.ca/mgoodyea/Documents/UK/crimereduction052a.pdf (accessed 12 November 2016).

Lipsky M. (1980) Street-Level Bureaucracy: Dilemmas of the Individual in Public Services. New York: Russell Sage Foundation.

Lowman J. and Atchison C. (2006) Men Who Buy Sex: A Survey in the Greater Vancouver Regional District. The Canadian Review of Sociology and Anthropology/La Revue Canadienne de Sociologie et d'Anthropologie 43(3): 281-296.

Lukes S. (1974) Power: A Radical View. London: Palgrave Macmillan Press.

Macleod J., Farley M., Anderson L. and Golding J. M. (2008) Challenging Men's Demand for Prostitution in Scotland. Women's Support Project \& Prostitution Research and Education, Glasgow, http://www.prostitutionresearch.com/pdfs/ChallengingDemandScotland. pdf (accessed 12 November 2016).

Månsson S.-A. (2004) Men’s Practices in Prostitution and Their Implications for Social Work. In Månsson S.-A. and Proveyer C. C. (eds.), Social Work in Cuba and Sweden: Achievements and Prospects. Gothenburg and Havana: University of Gothenburg and University of Havana. http://citeseerx.ist.psu.edu/viewdoc/download?doi=10.1.1.645.745\&rep=rep1 \&type $=$ pdf (accessed 12 November 2016).

Monto M. A. and McRee N. M. (2005) A Comparison of the Male Customers of Female Street Prostitutes With National Samples. International Journal of Offender Therapy and Comparative Criminology 49(5): 505-529.

O'Connell Davidson J. (1998) Prostitution, Power and Freedom. Oxford and Cambridge: Polity Press. 
Person E. S. (1980) Sexuality as the Mainstay of Identity: Psychoanalytic Perspectives. Signs 5: 605-630.

Skilbrei M.-L. (2012) The Development of Norwegian Prostitution Policies: A Marriage of Convenience Between Pragmatism and Principles. Sex Research and Social Policy 9(3): 244-257.

Strauss A. and Corbin J. (1990) Basics of Qualitative Research: Grounded Theory Procedures and Techniques. Newbury Park, CA: Sage.

Sullivan B. (2007) Rape, Prostitution and Consent. Australian \& New Zealand Journal of Criminology 40(2): 127-142.

Træen B., Eek-Jensen L. M. and Stigum H. (2005) Sex Customers in Norway 2002. Electronic Journal of Human Sexuality, 8, http://www.ejhs.org/volume8/Sex_Norway.htm (accessed 12 November 2016).

West C. and Zimmerman D. H. (1987) Doing Gender. Gender and Society 1(2): 125-151.

\section{Parliamentary References}

Great Britain, House of Commons Public Bill Committee Debates (27 November 2007) Criminal Justice and Immigration Bill Committee, vol. n/a cols. 539-568, http://www.publications. parliament.uk/pa/cm/cmpbcriminal.htm (accessed 12 November 2016).

Great Britain, House of Commons Hansard Parliamentary Debates (18 December 2008) First Reading of the Policing and Crime Bill 2008-2009, vol. 485, col. 1262, http://www. publications.parliament.uk/pa/cm200809/cmhansrd/cm081218/debindx/81218-x.htm (accessed 12 November 2016).

Great Britain, House of Commons Hansard Parliamentary Debates (19 January 2009) Policing and Crime Bill Debate, vol. 486, cols. 525-590, http://www.parliament.the-stationeryoffice. co.uk/pa/cm200809/cmhansrd/cm090119/debindx/90119-x.htm (accessed 12 November 2016).

Great Britain, House of Commons Public Bill Committee Debates (29 January 2009) Policing and Crime Bill Committee, vol. n/a, cols. 91-118, http://www.publications.parliament. uk/pa/cm200809/cmpublic/cmpbpol.htm (accessed 12 November 2016).

Great Britain, Joint Select Committees (16 April 2009) Human Rights Joint Committee Tenth Report, Legislative Scrutiny: Policing and Crime Bill, http://www.publications.parliament. uk/pa/jt200809/jtselect/jtrights/68/6802.htm (accessed 12 November 2016).

Great Britain, House of Commons Hansard Parliamentary Debates (19 May 2009) Policing and Crime Bill Debate, vol. 492, cols. 1398-1471, http://www.publications.parliament. uk/pa/cm200809/cmhansrd/cm090519/debindx/90519-x.htm (accessed 12 November 2016).

Great Britain, House of Lords Bill (21 May 2009) Bill 48 "Policing and Crime Bill" as brought from the House of Commons on 20 May 2009, http://www.publications.parliament.uk/ pa/ld200809/ldbills/048/09048.i-v.html (accessed 12 November 2016).

Great Britain, House of Lords Hansard Parliamentary Debates (3 June 2009) Second Reading of Policing and Crime Bill, vol. 711, cols. 231-284, http://www.publications.parliament.uk/ pa/ld200809/ldhansrd/index/090603.html\#contents (accessed 12 November 2016).

Great Britain, House of Lords Hansard Parliamentary Debates (1 July 2009) Policing and Crime Bill Committee, vol. 712, cols. 238-279, http://www.publications.parliament.uk/pa/ ld200809/ldhansrd/index/090701.html\#contents (accessed 12 November 2016).

Great Britain, House of Lords Bill (21 October 2009) Policing and Crime Bill as Amended in Committee, http://www.publications.parliament.uk/pa/ld200809/ldbills/074/09074.i-vi. html (accessed 12 November 2016). 
Great Britain, House of Commons Hansard Parliamentary Debates (2 December 2013) Daily Hansard - Written Answers, http://www.publications.parliament.uk/pa/cm201314/ cmhansrd/cm131202/text/131202w0002.htm\#131202w0002.htm_spmin3 (accessed 12 November 2016).

Great Britain, House of Commons Hansard Parliamentary Debates (13 October 2015) Daily Hansard - Westminster Hall, http://www.publications.parliament.uk/pa/cm201516/ cmhansrd/cm151013/halltext/151013h0001.htm (accessed 12 November 2016). 